\title{
Resensi
}

\section{Reformasi Konstitusi Belum Selesai}

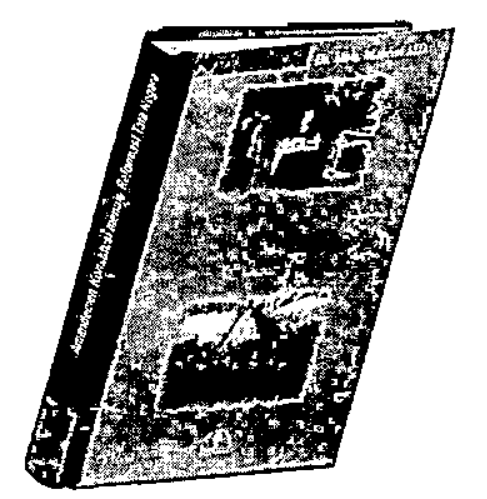

Judul buku

Penulis

Penerbit

Tebal
: Amandemen Konstitusi Menuju Reformasi Tata Negara

: Prof. Dr. Moh. Mahfud MD

: Ull Press, Cetakan I Agustus 1999

: ix +131 halaman

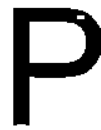

erkembangan ketatanegaraan Indo nesia memasuki era reformasi secara akademis memang sangat cepat. Gerak demokrasi, kebebasan pers dan politik misalnya, berjalan demikian pesat. Bahkan karena terlalu cepat sejumlah analis politik dan hukum pernah mengkhawatirkan bahwa "demokrasi" kita telah kebablasan. Atas dasar itu para analis tadi memberi solusi agar ada rambu-rambu terutama hukum dan moral yang dapat menjadi bingkai gerak demokrasi tadi agar tetap terkendali. Intinya tak lain agar konsep dan implementasi demokrasi ada semacam "konsolidasi" sehingga tetap dalam koridor yang diidealkan (on the track).

\section{Komitmen Reformasi}

Mengamandemen UUD 1945 seiring bergulirnya reformasi telah menjadi komitmen awal para reformis kala itu. Ketika Pemilu 1999 bergulir sejumlah Parpol kecuali PDIP seperti PAN, PKB, PPP, PBB - bahkan Golkar turut bersepakat mendukungnya. Mereka beranggapan salah satu "biang" mengapa di era Orde Baru dan Orde Lama sistem politik kita bersifat otoritarian dan tak memberi ruang pada demokrasi, tak lain akibat UUD 1945 memiliki kelemahan yang cenderung executive heavy; yang merupakan sumber penyebab politik menjadi otoritarian. Selain itu dengan kekuasaannya yang tak terukur (luasnya) Presiden dapat dengan seenaknya menerjemahkan teks UUD 1945 hanya untuk kepentingan kekuasaannya. Karena itu mengamandemen konstitusi merupakan keharusan sebagai salah satu visi reformasi. Penulis buku ini termasuk dalam "kubu" yang menyepakati amandemen itu.

\section{Substansi Amandemen}

Buku ini secara waktu (timing) memang telah lewat karena ketika diterbitkan 1999 dimaksudkan masih sebagai lontaran wacana amandemen yang dulu memang menemui banyak hambatan. Sedang saat ini UUD 1945 telah diamandemen sebanyak empat kali. Karena itu ada baiknya jika kita merevieuw kembali substansi amandemen 
yang kini sebetulnya belum juga dianggap memuaskan oleh berbagai pihak terutama beberapa pasal yang dianggap masih kontroversial (debatable).

Pertama-tama usai amandemen ke-IV dilakukan banyak orang menyoal bahwa, dengan tidak diubahnya Pembukaan yang merupakan kesepakatan seluruh anggota DPR, bukan berarti serta merta (implisit atau de facto) substansinya tidak berubah. Sebab 75 persen materi UUD 1945 telah berubah, berarti substansi-nyapun mestinya berubah.

Patut dicatat bahwa Pembukaan UUD 1945 mengandung beberapa pokok pikiran, antara lain (a) Negara Indonesia adalah negara kesatuan, berdasarkan persatuan dengan mewujudkan keadilan sosial bagi seluruh rakyat Indonesia. (b) Negara Indonesia berkedaulatan rakyat, berdasarkan atas kerakyatan dan permusyawaratan perwakilan.

Ciri utama dari kedaulatan, menurut Jean Bodin adalah: kekuasaan untuk menetapkan hukum bagi warga negara secara umum maupun secara individual serta menjatuhkan sanksi terhadap siapapun yang tidak menjalankan hukum tersebut. Kedaulatan juga mengandung arti wibawa tertinggi (supreme power).

Dalam ilmu ketatanegaraan dikenal tiga sumber utama wibawa tertinggi negara (locus of sovereignity), yaitu kedaulatan rakyat, kedaulatan hukum, dan kedaulatan negara. Apapun sumber atau locus dari kedaulatan itu, haruslah berbentuk institusi atau perlengkapan negara berupa subjek hukum. Di Amerika, konggres adalah pemegang dan pelaksana kedaulatan tertinggi negara. Sedang di Inggris sovereignty of parliament yang berarti parlemen adalah pemegang dan pelaksana tertinggi negara. Lalu yang menjadi pertanyaan, di mana locus of sov- ereignty di negara Indonesia?

Di dalam Pasal 1 ayat (2) UUD 1945 (sebelum diamandemen) menyatakan "Kedaulatan ada di tangan rakyat yang dilaksanakan sepenuhnya oleh Majelis Permusyawaratan Rakyat". Ketentuan ini mengandung makna bahwa kita menganut falsafah kedaulatan yang dilaksanakan sepenuhnya (supreme power) oleh MPR. Namun, pada Sidang Tahunan 2001, ketentuan ini diubah menjadi, "Kedaulatan berada di tangan rakyat dan dilaksanakan menurut Undang-Undang Dasar". Dengan rumusan baru ini, di mana letak locus of soveregntynya? Apakah di UUD? Bukankah UUD bukan subjek hukum yang tidak bisa melakukan tindakan hukum.

Dengan mengatakan kedaulatan rakyat dilaksanakan menurut Undang-Undang Dasar, bangsa ini tidak lagi memiliki sebuah institusi atau lembaga negara yang memiliki kewibawaan seperti dikemukakan Jean Bodin di atas, atau seperti yang kita temui di Inggris atau Amerika. Atau secara hukum tata negara, kita telah melenyapkan eksistensi MPR. Karena itu, substansi amandemen dalam konteks ini dengan Pembukaan telah bergeser menjadi absurd. Uniknya kendati pada Pasal ini, kewenangan MPR telah "dimusnahkan" pada tataran implementasi klaim bahwa MPR sebagai pemegang tertinggi kedaulatan rakyat masih tetap. Sebagai contoh melalui amandemen Pasal 3 ayat (1) dinyatakan "berwenang mengubah Undang-Undang Dasar." Padahal mereka sadar betul bahwa Undang-Undang Dasar merupakan sumber dari segala sumber hukum (fundamental law). Pada pasal ini jelas, ketidaksejalanan akibat antara pembukaan dan pasalnya telah terjadi ketidak-konsistenan akibat "ketidakritisan" para anggota MPR memahaminya. Hal inilah. yang mengesankan amandemen oleh MPR 
itu kebablasan.

Fokus yang juga patut diperhatikan adalah pada amandemen Pasal 22 ayat (2) UUD 1945; "Dewan Perwakilan Daerah ikut membahas rancangan undang-undang yang berkait dengan otonomi daerah; pembentukan, pemekaran dan penggabungan daerah; serta memberikan pertimbangan kepada Dewan Penwakilan Rakyat atas rancangan undang-undang anggaran pendapatan dan belanja negara dan rancangan yang berkaitan dengan pajak, pendidikan dan agama."

Pada pasal ini sangat jelas wewenang DPD demikian luas yang cenderung memborong seluruh persoalan penting. Yang tersisa nampaknya tinggal persoalan politik luar negeri, hankam dan moneter. Lembaga ini kehadirannya sangat mengkhawatirkan. Bayangkan saja andaikan DPD tidak menyetujui sebuah RUU mengenai perimbangan keuangan pusat dan daerah atau RUU APBN, apakah DPD bisa di-fait a commpli atau dead lock akan terjadi? Kehadiran DPD dikhawatirkan akan melahirkan "daerah sentris" di seluruh nusantara. Sekarang saja, dengan UU No. 22 dan No.25 Tahun 1999 tentang Pelaksanaan otonomi Daerah dan Perimbangan Keuangan Pusat dan Daerah, di banyak daerah telah melahirkan "raja-raja kecil" yang amat powerful, apalagi 'nanti jika lembaga ini mulai "beraksi".

Mereka, "raja-raja kecif" itu, misalnya, bisa melecehkan kekuasaan gubernur. Mereka dapat seenaknya mengeluarkan izin penebangan kayu, izin penangkapan ikan, dan sebagainya yang sebelumnya kewenangan itu ada pada gubernur. Gubernur dilecehkan karena mereka berkeyakinan bahwa "yang punya rakyat" dan "yang punya kekayaan alam" adalah bupati bukan gubernur.
Kehadiran DPD dengan sendirinya akan memperlemah wibawa pemerintah pusat dan merontokkan efektivitas perintah-perintah pusat ke daerah.

Sebenarnya, konsep DPD memang diadopsi dari negara federasi yang sangat bertentangan dengan prinsip-prinsip pokok negara kesatuan yang tegas-tegas diamanatkan di dalam Pembukaan UUD 1945.

Pasal berikutnya yang patut dikritisi adalah Pasal 22E ayat (3). Secara umum terkesan para wakil rakyat di MPR itu sangat ingin bereksperimen melakukan pemilihan presiden secara langsung (one man one vote); namun di sisi lain dikatakan oleh Pasal itu , peserta Pemilu untuk memilih anggota DPR dan DPRD tetap Partai Politik. itu berarti, peserta Pemilu anggota DPD juga perorangan. Mengapa tidak semuanya saja dipilih secara langsung, tanpa perantara Parpol, seperti yang terjadi di Amerika. Dari Pasal ini jelas, para wakil rakyat itu tidak cukup "PD" untuk terjun dalam Pemilu langsung tahun 2004. Mereka inkonsisten.

Akhirnya patut dikemukakan bahwa para elit politik yang mengaku "reformis" itu telah gagal dalam menangkap tujuan dari amandemen UUD 1945. Tujuan utama amandemen adalah demi kepastian, supaya UUD 1945 tidak multi-interpretasi. Namun, dalam kenyataannya, hasil karya mereka pun, sebagian besar bersifat "Pasal Karet" yang debatable. Ini berarti ketika tiba pada masalah untuk menentukan interpretasi mana yang paling benar tetap sulit, dan jamak terjadi dan terulang kembali interpretasi itu akhirnya tetap dilakukan oleh yang sedang berkuasa.

Melihat kenyataan masih "rapuh"nya amandemen yang ada, nampaknya kita layak mewacanakan kembali, bahwa yang dibutuhkan nampaknya memang bukan 
sekadar amandemen melainkan, konstitusi baru. Sobirin Malian pernah mewacanakan itu melalui bukunya berjudul Gagasan Perlunya Konstitusi Baru Pengganti UUD 1945. Yang menjadi soal melalui pintu mana wacana itu dapat diusung ke MPR sehingga tertampung.

Buku Moh. Mahfud MD ini, sekali lagi ketika diterbitkan barulah lontaran wacana agar amandemen UUD 1945 dilakukan, dan itu telah terlampaui. Persoalannya kemudian seperti telah diuraikan amandemen 1 hingga 4 itu ternyata tetap mengandung kelemahan mendasar. Efek dari amandemen itupun sejauh ini substansinya belum signifikan. Karena itu, layak kiranya wacana penggantian dilontarkan kembali seperti yang pernah terjadi di Thailand, Filipina, Afsel dan lain-lain

Sobirin Malian

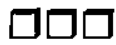

